\title{
THE IMPACT OF GLOBALIZATION ON THE EMERGENCE AND DEVELOPMENT OF CRISIS
}

\author{
Oksana Mykhailovska \\ Chernivtsi Trade and Economics Institute of KNTEU, Chernivtsi, Ukraine
}

(C) MESTE NGO

JEL category: A23, I23, L26

\begin{abstract}
The causes and evolution of events and trends that determine the development of the crisis are analyzed in the article. In the article we determine that the management of competitiveness of socio-economic systems in the context of globalization is closely intertwined with the anti-crisis management, not only at the enterprise level, but also at the regional and national economies. It is established that under the conditions of global competition countering crises should be directed to ensure a quasi-crisis counter pressure. Globalization dialectically affects the frequency and degree of manifestation of the crisis in social and economic systems. On the one hand, due to the activities of international financial institutions countering crises is made in particular countries, but the impact of globalization on increasing and strengthening the manifestation of crises in social and economic systems of various ranks is much wider. The competition for resources between social and economic subsystems is one of the main blocks of contradictions. Mentioned subsystems are present in the socio-economic systems at all levels. In the terms of global competition the availability of resources reduction threats becomes of the most importance in the management of socio-economic systems. These resources are necessary for the system that brings to the fore a long-term (strategic) management horizon to ensure a minimum level of resources to deal with constant quasi-crisis pressure.
\end{abstract}

Keywords: crisis, systemic crisis, socio-economic systems, anti-crisis management, quasi-crisis pressure, global competition, rank positions

\section{STATEMENT OF THE PROBLEM}

To prevent and avoid negative scenarios of socioeconomic systems development it is needed to understand clearly the causes of occurrence and development of events and trends which determine the evolution of the crises. To establish the causes of the crises it is necessary to determine the range of objects which are inherent

Address of the author:

Oksana Mykhailovska

麦三” ooovvv@mail.ru in the crisis, to find out the nature of crisis, their types, and only then to find out common causes of various types of crises in different socio-economic systems.

First it is needed to determine in which socioeconomic systems crises may arise: enterprise, regional or national economy, or the global economy as a whole.

Analysis of recent researches and publications. If we analyze the crisis in the socio-economic system of national ranking, the external factors for 


\section{Mykhailovska $O$. The impact of globalization on crisis}

MEST Journal Vol. 2 No. 2 pp. 149-158

it will be negative or crisis phenomena in the global economic system. A. Halchynskiy (2009, p. 92) rightly points out that the national economy as a structural division of the world system is subordinated to its laws and specifics. After determining systems where crisis phenomena are possible, we can analyze their essence. Despite the considerable attention to the crises and crisis phenomena in recent years, their nature hasn't been clearly defined yet. There are many definitions of "crisis". V. Shpachuk (2010) presents nine definitions of "crisis" in social and economic systems of different ranks, G. Buslajeva (2007) presents 15 definitions. A large number of approaches to the essence of the notion "crisis" are presented.

The aim of the article is to analyze the crisis in socio-economic systems of different levels in the context of globalization.

\section{ANALYSIS}

It should be mentioned that not enough attention is paid in the literature to the specifying of contradictions, imbalance between which, is resulted in the crisis, but the same time determines the evolution (development) of socioeconomic systems. After reviewing the scientific literature on the problems and contradictions of the crisis development in socio-economic systems (Oleshko, 2010), we consider that it is logically to distinguish between three main blocks of dialectical contradictions in socio-economic systems, imbalance between which, is resulted in the development of crises phenomena (fig.1)

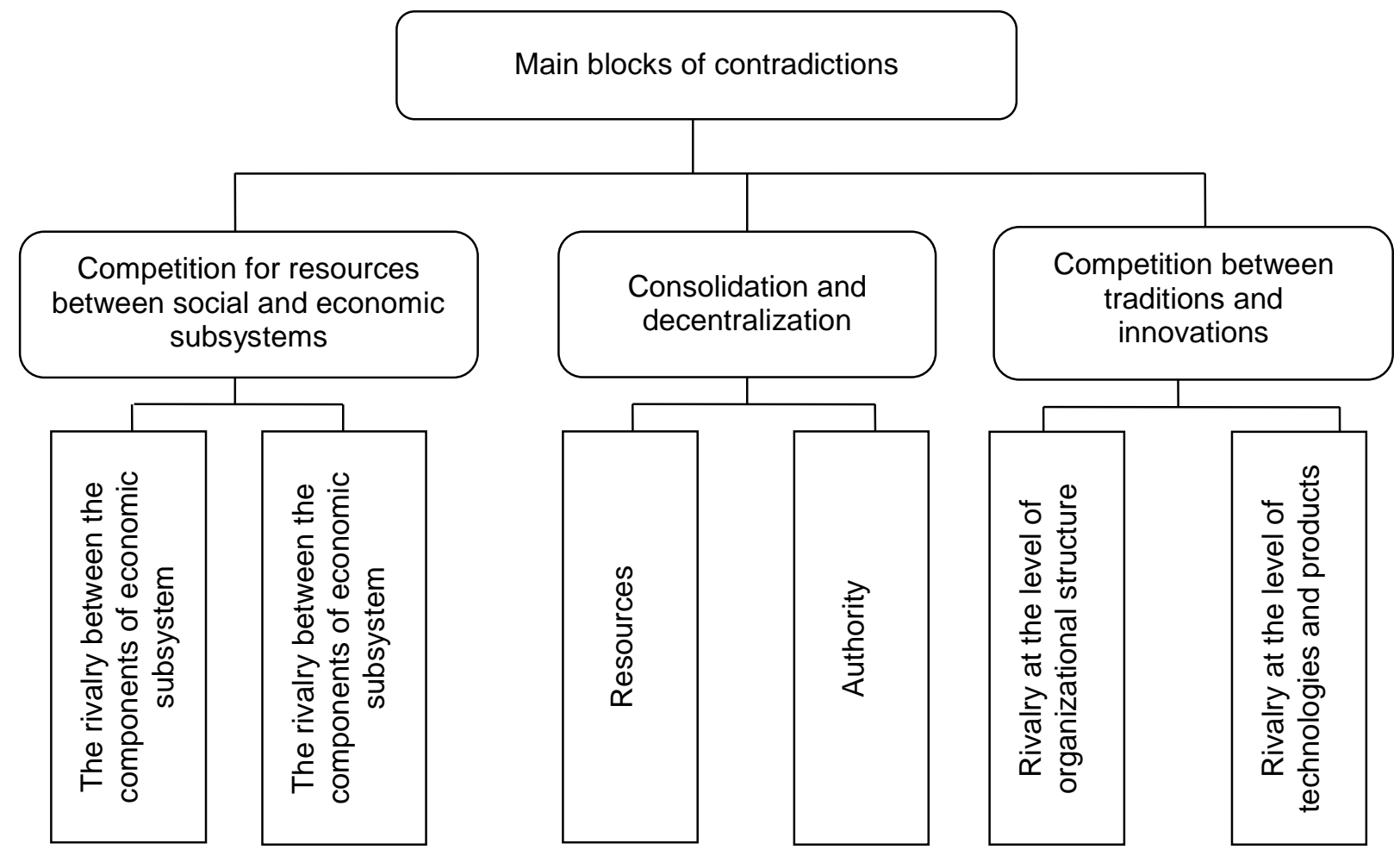

Figure 1. The main blocks of dialectical contradictions in social and economic systems. Source: developed by the author

One of the main blocks of contradictions in social and economic systems of different ranks is the competition for resources between social and economic subsystems. Mentioned subsystems are presented in the socio-economic systems at all levels. Subjects of control permanently solve the dilemma: to increase support for the economy of the country or the budget expenses for social needs (at the level of the national economy), or to spend the extra income on the extension (upgrades) of the production or to stimulate the staff (at the company level). The placement and maintaining of the balance in the allocation of resources is challenging task and is associated with the competition, while to meet the needs for resources of subsystems, the resources given in competitive rivalry are needed. While analyzing international competitiveness of the national economy L. Antonjuk (2004, p. 12) emphasizes that it should provide both "the implementation of 
national interests for the sake of economic security" (to provide national economy with resources) and "high living standards" (to provide social subsystem with resources). Accordingly, competition for resources may occur between the individual components of subsystems: branches, divisions, enterprises, etc.

The second block of contradictions is consolidation and decentralization. Each socioeconomic system has a struggle and balance between mentioned contradictions: from the global economic system to the enterprise.

The third block of contradictions is the rivalry between "new" and "old". J. Shumpeter (2008, p. 389) noted that no new "grows with the old, but it is next to it, then displacing it".

The socio-economic system of any rank from the enterprise to the global economy is dynamic. Its condition at a definite point of time differs from the previous and will differ from the future condition.
Certain area of the set of all possible states of the socio-economic system is considered to be "normal", and the other - "crisis". Splitting of the sets of system states into "acceptable" (normal) conditions and the conditions which are interpreted as negative is usually done from the position of its development (Fomina \& Pryxod'ko, 2012). The basis assumption, as has already been mentioned, is the availability in each system dialectically connected to opposite processes. Then the "normal", or safe condition of a system can be logically defined as the one in which there is a balance of the mentioned pairs of processes. M. Fomina and V. Pruhodko states that such a balance balances destruction and renewal, decay and combination, separation and integration in the frames of the system (Fomina \& Pryxod'ko, 2012, p. 436), and thus ensures its existence and dynamics as a whole. If the balance of opposites is broken in the system, so its state is considered to be negative, and in the case of major violations it is considered to be crisis.

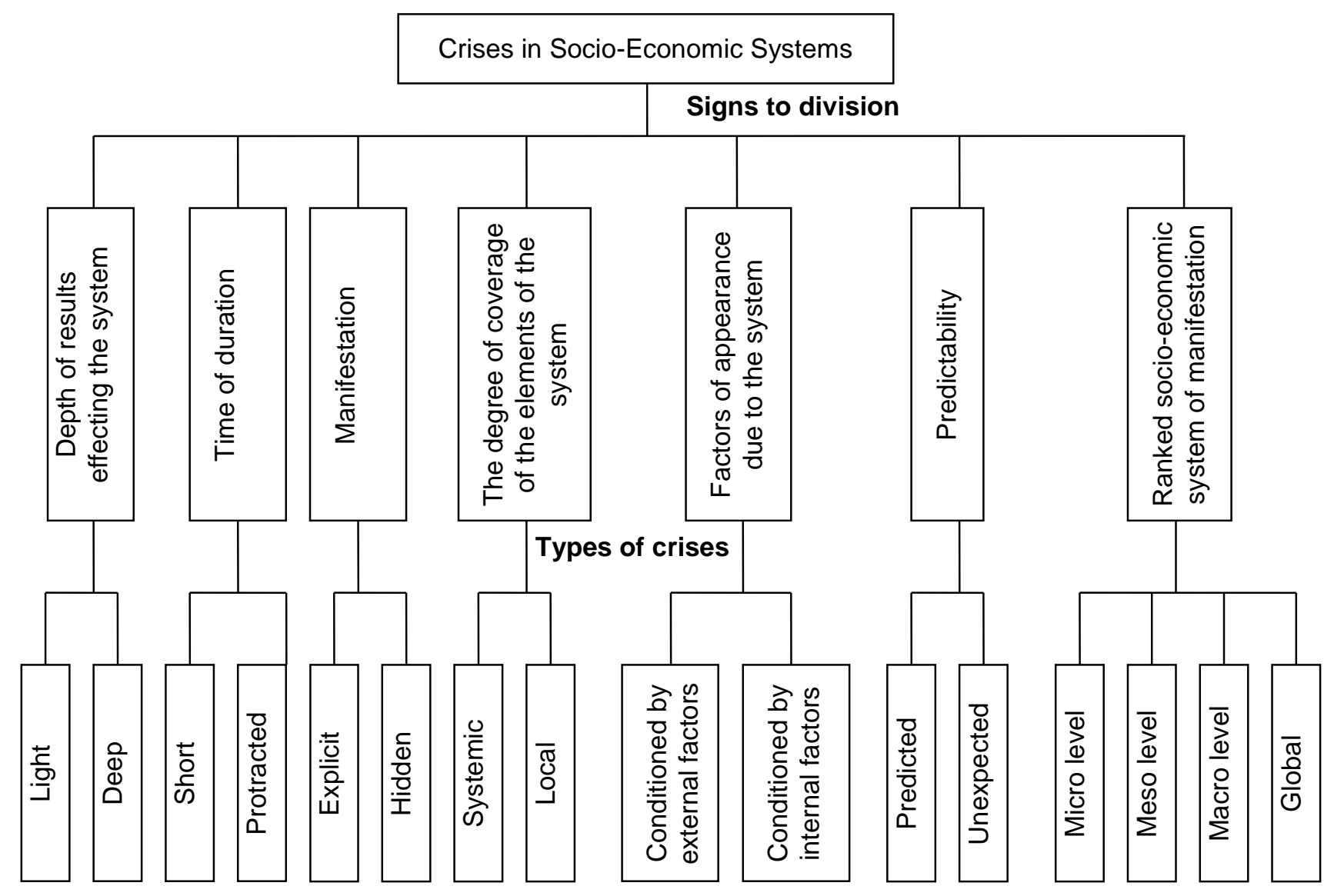

Figure 2. Classification of crisis in socio-economic systems. Source: developed by the author based on (Slizkova, 2012) 
Therefore, it's more logically to believe that the intensification of contradictions in the system leads to crisis phenomena, that could escalate to crisis (the system enters to a new state), but they may be liquidated due to certain influences (internal and external) and the system will continue to function in the same state or condition. So, we'll understand under the term "crisis" crisis phenomena because it's impossible to distinguish whether the crisis phenomena is really a crisis or if they are removed without switching to a new state.

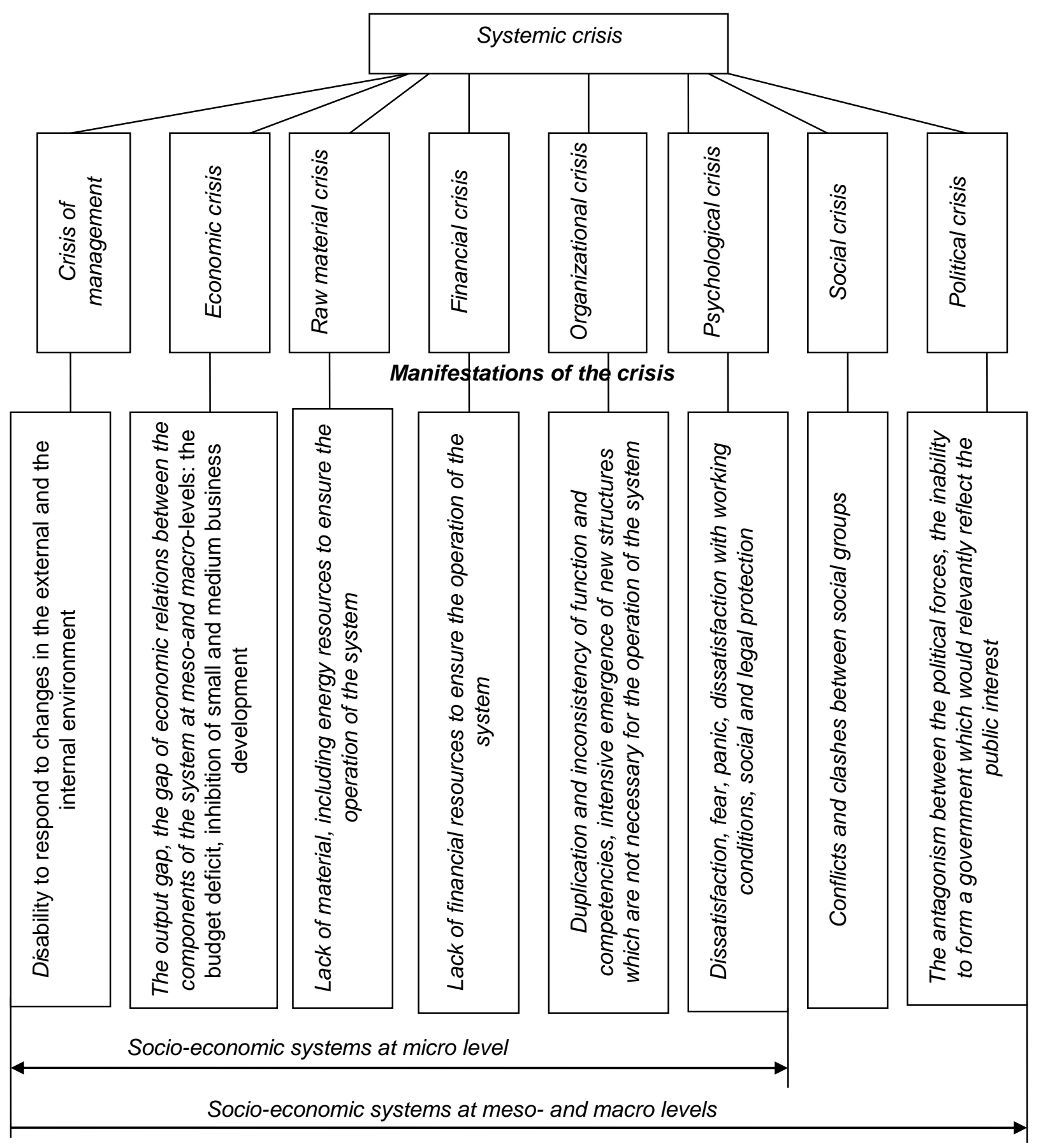

Figure 3. Basic components of a systemic crisis and its manifestations in social and economic systems. Source: developed by the author based on (Paxomova, 2008)

The complexity of socio-economic systems causes the variety of contradictions in them, and thus the difference in crises. Therefore there is a need to classify crises in socio-economic systems 
according to their main features. Regarding to the approaches to classification of crises in social and economic systems, the sources analysis on this issue (Slizkova, 2012) allows us to identify several signs of classification (fig.2).

In general, every crisis is unique as to the degree of influence on the economic system, the length, the degree of coverage of elements in the system, and other characteristics. It should be mentioned that there is more detailed classification of crises in the social and economic systems. V. Shpachuk distinguishes eleven signs of their classification (mentioned author calls them "classification criteria".

In terms of impact on the functioning of social and economic system an important feature of crisis is the degree of coverage of main components of the system. It is logical to assume that a systemic crisis is always deeper, longer, caused by a complex web of internal and external factors. The combination of local crises is a systemic crisis (fig. 3).

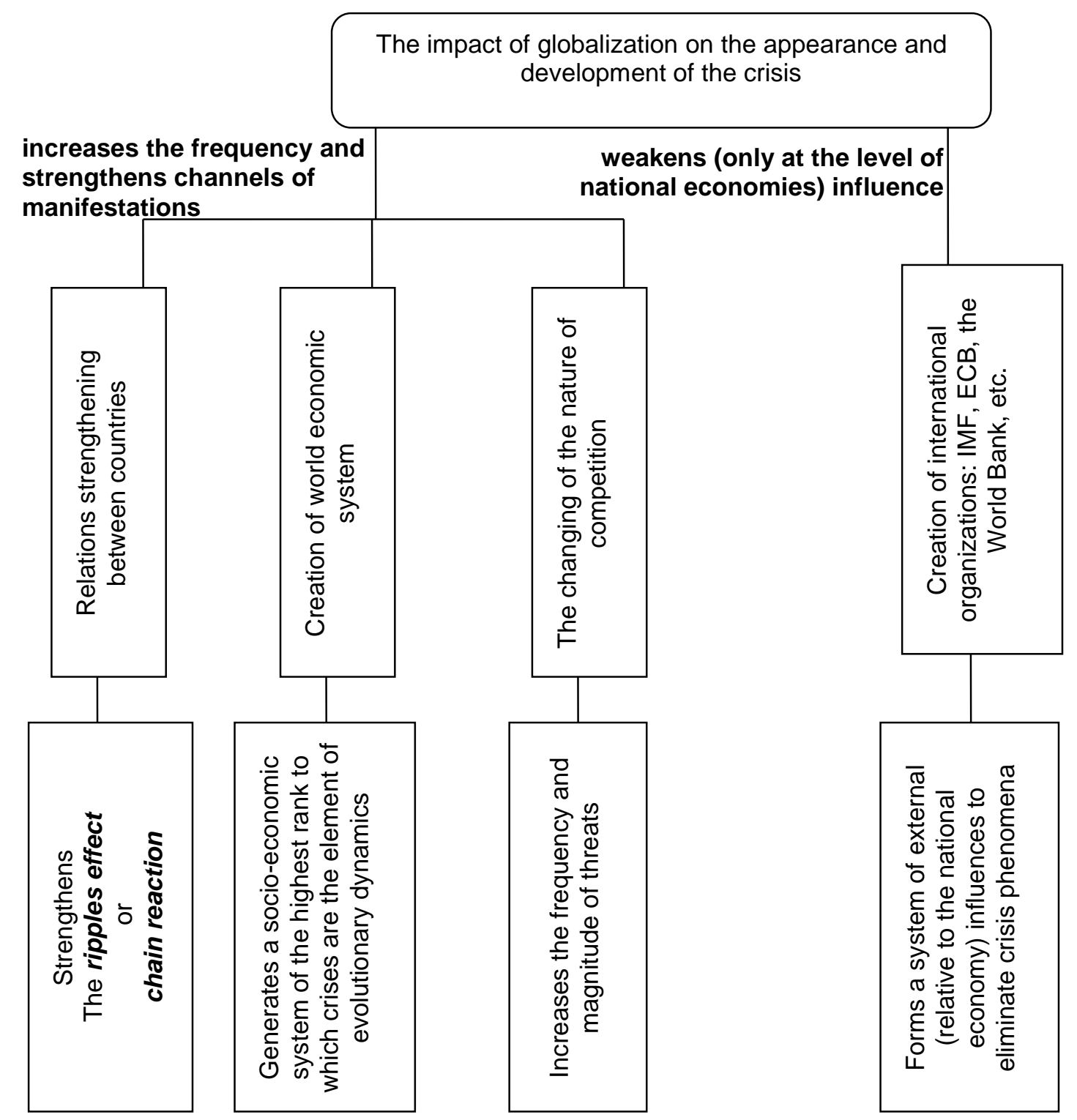

Figure 4. The impact of globalization on the appearance and the development of the crisis in social and economic systemsSource: developed by the author

It should be mentioned that crisis phenomena that match partial crises are interrelated. In this aspect the idea of L. Sytnyk seems to be right, that the crisis situation of the company is characterized by a specific sequence, which includes a chain of economic phenomena related to the causation 
(Sytnyk, 2003). This suggestion is applied to the social and economic systems of higher ranks, but the list of phenomena should be expanded from the economic to the socio-economic (including psychological).

Thus, the economic crisis will worsen the possibility of logistical and financial support, conditions of financing, and will cause psychological crisis and social crisis. The appearance of the crisis phenomena in one of the areas of socio-economic system functioning causes the appearance or worsening of the crisis phenomena in another. The opposite sequence can also be set. So, this approach corresponds to the cyclic self-strengthening of crisis phenomena in the major areas of functioning of the socioeconomic system. A kind of "crisis cycle" (Dubyns'ka, 2010), or so called "ripples effect" when the crisis is compared with the appearance of waves during the falling of stones into the water (Hit, 2002, p. 23) and can cause and accelerate a number of other crisis situations or crises. "The ripples effect" determines the "chain reaction (Korotkov, 2003), the essence of which is in the distributing of local crisis (crisis in one part of the system) to the entire system, and in some cases to the other socio-economic systems.

Based on the logic of systems analysis and the relations of threats to the competition (competition is a part of the external factors) it is logical to highlight four channels of globalization impact on the appearance and development of the crisis phenomena in social and economic systems (fig. 4).

First we would like to emphasize that globalization makes dialectical impact on the appearance and development of the crisis: while increasing and decreasing the frequency of occurrence and degree of manifestation.

In the present world economic system a number of international organizations such as: the IMF, the World Bank, the ECB, and others have been created. These organizations, in some cases, provide advice and financial assistance to various countries in order to eliminate the crisis.

We consider that the following examples are very illustrative. Major crisis (GDP falling reached almost 10\%) was observed in Mexico in 1995, but thanks to the financial support of the IMF, the coordinated actions of USA, and other developed countries it was a short-term crisis. Another examples are the currency crisis in South-East Asia countries, that has been eliminated with the help of IMF; financial support of Greece in 2012 by the EU and other examples. In some cases, such "external" support helps to avoid destructive reconstruction of socio-economic system of the national rank and return it to the state in which it was before the development of crisis phenomena. However, mentioned positive effect of globalization on the crisis exists only at the level of socio-economic systems for the rank of national economies and partly for the level of world economy. For the systems of other ranks it is missing.

Three other channels of globalization influencing the crisis lead to the increased frequency of their occurrence and depth of expression.

Strengthening of interrelations between countries leads to the increase of their interdependence on each other. Under the conditions of globalization business entities in one country become dependent on markets and resources of other countries. For socio-economic systems at the rank of enterprises the external environment under the global conditions is not socio-economic system of higher rank (national economy), which includes the enterprise, but socio-economic systems of higher rank. Thus, in the context of globalization "the ripples effect" has an international character: negative phenomena in one country can cause threats for enterprises activity in the other and through them carries a negative effect on its state.

By changing the nature of competition, globalization affects the appearance and development of the crisis in social and economic systems of various ranks. Under the conditions of increasing dynamics, multi-aspects, multi-market systems, and aggressive competition, negative phenomena in the external and internal environment of social and economic systems arise continuously. Mostly they have a local impact on the activity of the socio-economic system, that's why it is more correctly to call them "quasi-crisis". A continuous set of such events and trends creates a permanent impact on the business, which can be called quasi-crisis pressure. S. Medvedev indicates to the presence of a certain constant action of the external environment on the 
socio-economic system. He points out that external factors in the external environment are putting pressure on business structures, while internal factors should resist such pressure (Medvedev, 2010, p. 48). The mentioned author believes, that such pressure acts only in times of crisis, however, it is logical to believe that anticrisis pressure on the socio-economic system is a permanent phenomenon, every time there is its interaction with the external environment. As a result anti-crisis measures should not be done at a particular point of time, but constantly in order to prevent the escalation of the quasi-crisis pressure into the crisis.

Let's dwell briefly on the nature of the events (threats) that create quasi-crisis pressure under the conditions of globalization.
First of all, increased aggressiveness of competition under conditions of globalization leads to the existent of a constant struggle for the inflow of resources needed for the development of the socio-economic system. The most important such resources in modern terms are the financial capital (investment) and intellectual capital (human resources). In the XXI century we can state the formation of both global investments markets and human resources, especially those, associated with the intellectual capital. So, if for low-skilled employees in a number of countries special barriers are introduced in order to curb the influx of migrants, for foreign highly skilled employees and researchers, on the contrary, all conditions to encourage the arrival and employment are created (Poliščuk, 2009).

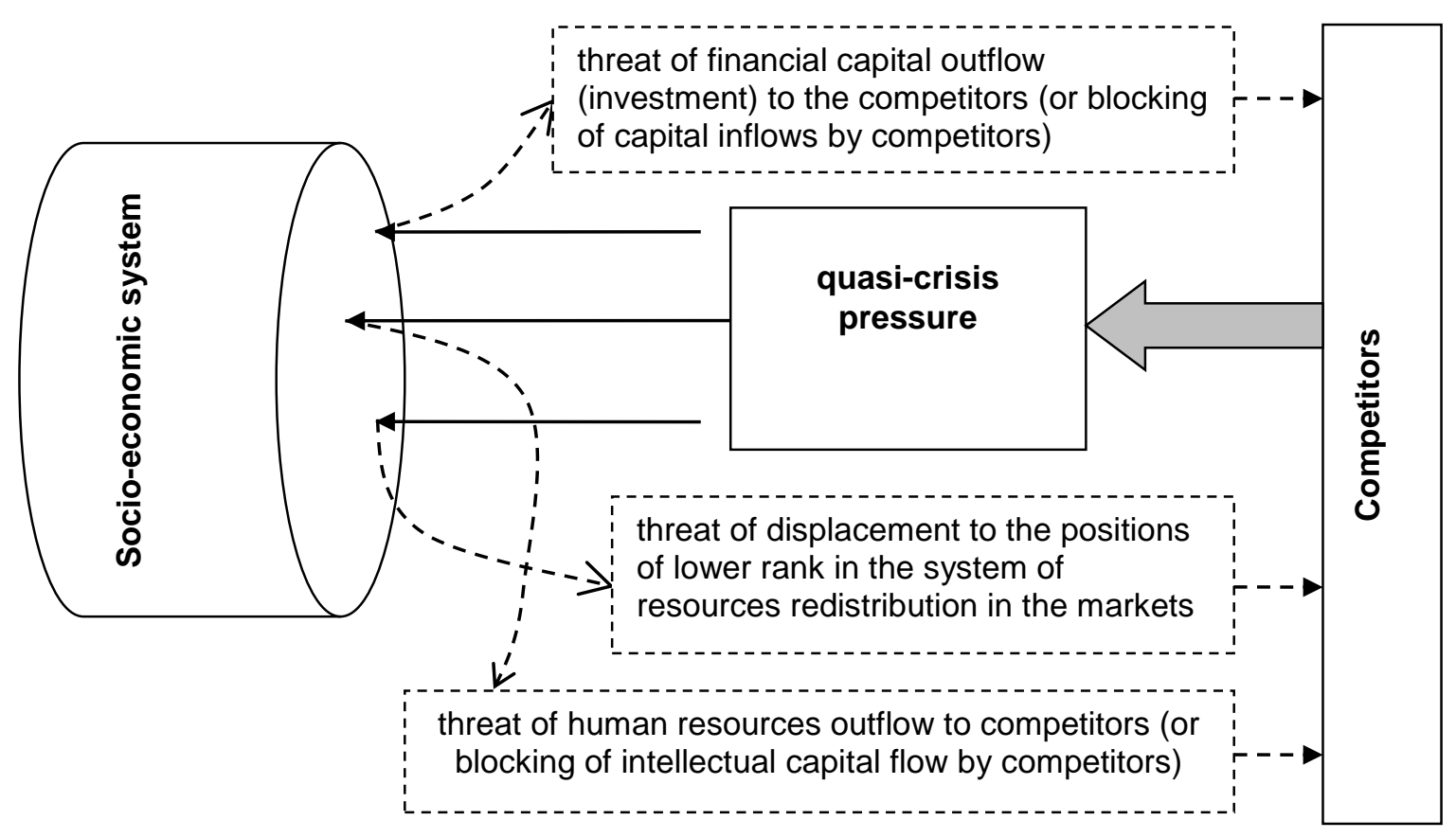

Figure 5. The essence of quasi-crisis pressure in terms of global competition Source: developed by the author

For the second, in the current context of globalization there is a significant amount of financial and intellectual capital, which is free from the use in a particular socio-economic system. But it becomes more and more difficult to engage it to the use because the other socio-economic systems try to make the same. If they do it, then the international flows of investment or intellectual capital bypass certain country or, on another level, - the enterprise. Then we consider that it is true to state "blocking" of flows of resources in the socioeconomic system. To prevent this it is needed to spend constantly some resources to maintain the proper level of appeal for those types of resources needed for the development.

It is logical to point out three blocks of threats which form a quasi-crisis pressure under the context of competitive environment and act on the socio-economic systems rank to the national economy and associations including: threats associated with the competition for financial capital; threats associated with the competition for the intellectual capital; and threats associated with 
competition for rank positions in the system of redistribution of income in the global market (fig.5).

Competition doesn't exist literally in the world economy as a whole, but it can be understood in a figurative sense, as a possible way of competition. In this case the resource market is expanding to the global ecosystem, and rank positions will mean composition of resources able to be used by the global economy as a whole for its development. Outflow of resources will mean the decrease of efficiency of their use and reducing of overall intellectual capital.

The outflow of financial resources will mean that less of them will be used in economic purposes, and more - to the elimination of negative impact of humanity on the ecosystem. Quasi-crisis pressure exists in the case of global economic system, but in the future we will consider it primary as a system of higher rank (external environment) to national economies. Indeed, based on the purpose and object of the research, crisis phenomena should be viewed from the standpoint of managing of socio-economic systems. In the case of world economy it's impossible to state now that effective mechanisms for its management on a global level as a whole social and economic system are produced. Therefore, it is logically to shift the main focus to socio-economic systems of lower rank.

\section{CONCLUSIONS}

Quasi-crisis pressure causes additional costs of social and economic system of a number of resources for its "restraint". Thus, if certain number of scientific personnel migrated from the country, it is needed to incur additional costs to train new professionals. If skilled workers left the company, it is necessary to spend extra funds to find new ones. If the loss of intellectual capital was compensated, the system continuous to operate as if outflows weren't existed. But additional resources have been spent for it. If their amount, allocated for compensation of quasi-crisis pressure was insufficient, or they weren't allocated at all, the resources base of the system starts to decrease (in this case due to the outflow of intellectual capital), quasi-crisis phenomena are accumulated and develop into a crisis. The same is true for financial capital. The above mentioned is the essence of the external manifestation of quasi-crisis pressure.

On the other hand, in the enterprise, in the region or country it is necessary to follow the working conditions, salary, and opportunities for development; social status was not lower than in the competitors. Otherwise an outflow of resources will be observed. This is an internal manifestation of quasi-crisis pressure.

The competition involves competition for certain rank positions in the system of redistribution of profits in certain markets. Therefore, there is a constant threat of displacement of rank position to a lower level position in the system of income redistribution. If the resulting gross profit is not enough to deter quasi-crisis pressure, crisis phenomena start to develop in the socio-economic system, because the system has no resources to deter quasi-crisis pressure. Thus in the global competitive environment socio-economic system must secure the following rank positions in the redistribution of income, which should at least be higher than the resources needed to compensate quasi-crisis competitive pressure, considering the amount of resources needed to support its operation.

So, in terms of global competition countering crises should be directed not only to avoid or eliminate adverse events or crises, but also to provide resistance to quasi-crisis pressure. Their appearance is the objective result of hyper competition, and therefore it is impossible to eliminate or prevent negative trends or phenomena at all. Instead, the subjects of management of socio-economic systems need to realize that to maintain the operation and maintenance of subjects of management development the constant resistance of quasicrisis pressure is needed. The last needs: a) a certain amount of resource support; b) the effective use of allocated resources.

In the terms of globalization of economic relations it is needed to state that the competitiveness management of socio-economic systems at different levels is closely interrelated with anticrisis management not only at the enterprise level, but also at regional and national economies. Without providing sufficiently high rank position in the market of profit redistribution, a company or a country sooner or later will face with the problem 
of lack of resources to counter quasi-crisis pressure from the competitive environment.

The above mentioned thesis is correlated with the concept of "normal profit" in the theory of the field equilibrium by J. Robinson. He determines the equilibrium at the market as the one in which there is no tendency to change the number of firms that operate in it, the profit which a company receives under the conditions of market equilibrium is "normal" (Robinson, 1933, p. 142). If the profit is less, then the companies will go out of the field (it is the destruction of enterprises as socioeconomic systems as a result of crisis). Average profit is actually equivalent to the minimum income in the terminology of $\mathrm{J}$. Robinson, and it allows resisting quasi-crisis pressure of competitive environment.

Therefore, the introduced and justified term "quasi-crisis pressure" allows combining the approach to competition as competition for ranked positions in the system of resources redistribution with the management of system development from the standpoint of preventing crises. Globalization dialectically affects the frequency and the degree of manifestation of crisis in socioeconomic systems. On the one hand, due to the activities of international financial institutions countering crisis is made in individual countries, but the impact of globalization on increasing and strengthening crisis manifestation in socioeconomic systems of various ranks is much wider. Such effect is done:

1. due to the strengthening of "chain effect" of crisis (as a result of interconnectedness of separate economics increase);

2. due to the appearance and formation of socioeconomic system of the highest level - world economy, in which the crises are objectively conditioned stage of evolutionary development;

3. by increasing of quasi-crisis pressure (due to changing of competition under the influence of globalization).

Therefore, prevention of the appearance and development of crisis to avert degradation of the system or its reduction becomes of a particular importance in the management of socio-economic systems in the terms of global competition.

Moreover, the presence of continuously existing threats to reduce the resources required for the operation of the system brings to the fore a longterm (strategic) horizon of management to ensure a minimum level of resources to deal with the constant quasi-crisis pressure.

\section{WORKS CITED}

Antonjuk, L. (2004). Konkurentospromožnist' nacional'noji ekonomiky v umovax hlobalizaciji: Avtoref. dys... d-ra ekon. nauk: 08.05.01. Kyiv: Kyjiv. nac. ekon. un-t.

Buslajeva, H. (2007). Problemy vyznačennja sutnosti ta pryrody kryzy pidpryjemstva. Kul'tura narodov Pryčenomor'ja(121), 17-19.

Dubyns'ka, O. S. (2010). Sutnist' i osoblyvosti ponjattja "kryza" v orhanizacijno-vyrobnyčij sferi pidpryjemstva. Aktual'ni problemy ekonomiky : naukovyj ekonomičnyj žurnal, 106(4), 102-108.

Fomina, M., \& Pryxod'ko, V. (2012). Modern Economic Development: Problems and Prosspects. Bjuleten' Mižnarodnoho Nobelivs'koho ekonomičnoho forumu. 5, pp. 435-436. Dnipropetrovsk: Alfred Nobel University.

Halchynskyi, A. S. (2009). Kryza i tsykly svitovoho rozvytku [The crisis and the global cycles of]. Kyiv: ADEF-Ukraina.

Hit, P. (2002). Kryzovyj menedžment dlja kerivnykiv. Kiev: Vseuvyto, Nauk. dumka.

Korotkov, E. (Ed.). (2003). Antykryzysnoe upravlenye: Uchebnyk. Moskva: INFRA-M.

Medvedev, S. (2010). Tendencyy y zakonomernosty ustojchyvosty razvytyja predprynymatel'skyx struktur v uslovyjax ekonomycheskoho kryzysa. Vestnyk tambovskoho unyversyteta, 81(1), 47-52.

Oleshko, A. (2010). Relationships of cycles and crises of various etymology in the dynamics of the socio-economic systems development. Bulletin of the International Nobel Economic Forum, 1(1), 241-247.

Paxomova, T. I. (2008). Shchodo mexanizmiv upravlinnja kryzamy suspil'noho rozvytku v systemi derzhavnoho upravlinnja. Teoretychni ta prykladni pytannja derzhavotvorennja(4).

Poliščuk, O. V. (2009). Mižnarodno-pravove rehuljuvannja trudovoji mihraciji naselennja: dys. ... kand. juryd. nauk : 12.00.11. Kiev: Ukr. derž. un-t finansiv ta mižnar. torhivli.

Robinson, J. (1933). The economics of imperfect competition. London: Macmilan. 
Shpachuk, V. (2010). Teoretyčni zasady typolohizaciji kryz. Naukovyj visnyk akademiji municypal’noho upravlinnja(4).

Shumpeter, J. (2008). The theory of Economic Development. Moskva: Directmedia Publishing.

Slizkova, G. (2012). Crisis in public administration in Ukraine: causes, development, ways of overcoming. Journal KNUTD, №2, pp. , 137-142.

Sytnyk, L. (2003). Organizational and economic mechanism of anti-crisis management of enterprise", author's abstract of PhD dissertation: 08.02.03. Donetsk: The Institute of Economics and Industry.

Received for publication: $\quad 31.01 .2014$

Revision received: $\quad 12.06 .2014$

Accepted for publication: $\quad$ 23.06.2014

How to cite this article?

Style - APA Sixth Edition

Mykhailovska, O. (2014, 07 15). The impact of globalization on the emergence and development of crisis. (Z. Čekerevac, Ed.) MEST Journal, 2(2), 149-158. doi:10.12709/mest.02.02.02.16

Style - Chicago Fifteenth Edition:

Mykhailovska, Oksana. 2014. "The impact of globalization on the emergence and development of crisis." Edited by Zoran Čekerevac. MEST Journal (MESTE) 2 (2): 149-158. doi:10.12709/mest.02.02.02.16.

Style - GOST Name Sort:

Mykhailovska Oksana The impact of globalization on the emergence and development of crisis [Journal] // MEST Journal / ed. Čekerevac Zoran. - Belgrade : MESTE, 07 15, 2014. - 2 : Vol. 2. - pp. 149-158.

Style - Harvard Anglia:

Mykhailovska, O., 2014. The impact of globalization on the emergence and development of crisis. MEST Journal, 15 07, 2(2), pp. 149-158.

Style - ISO 690 Numerical Reference:

The impact of globalization on the emergence and development of crisis. Mykhailovska, Oksana. [ed.] Zoran Čekerevac. 2, Belgrade : MESTE, 07 15, 2014, MEST Journal, Vol. 2, pp. 149-158. 